\title{
UNDERSTANDING THE ANTI-RADICALISM OF THE NATIONAL CIVIC FEDERATION
}

The labor historians Perlman and Taft provide us with an acceptable, if general, introduction to the National Civic Federation:

"The national organization was an outgrowth of the Chicago Civic Federation, organized in 1893, to bring about better relations between capital and labor and to promote the study of civic problems. The Chicago Civic Federation succeeded in averting a number of labor controversies, and in 1900, its chief promoter, Ralph Easley, sought to extend its range of activities. He founded the National Civic Federation, composed of capitalists, labor leaders, and representatives of the public."1

These students of John R. Commons do not go further into the dynamics of that very controversial body, perhaps because Commons was himself an active member involved in its work for a number of years. If we are to comprehend the interests and motivations of the forces represented by the Federation, however, we must examine widely conflicting perspectives for the NCF certainly evoked diverging verdicts as to its purposes. It is in this way, I believe, that we can ultimately gain a better comprehension of the fierce anti-radicalism it exhibited during and after World War I.

Marguerite Green's The National Civic Federation and the American Labor Movement 1900-1925, written in 1956 as a Ph.D. dissertation for the Catholic University of America, is the only major published work on the NCF. Philip Taft says: "mother Green's study is the authoritative examination of the Federation";2 her book represents the orthodox view of our subject. Mother Green essentially takes the high-sounding pronouncements of the Federation's leaders always at face value. When the energetic Easley brought Mark Hanna and Samuel Gompers (and other leaders of business and labor) together in

1 Selig Perlman and Philip Taft, Labor Movements [History of Labor in the United States, Vol. IV] (New York, 1935), p. 48.

2 Philip Taft, Organized Labor in American History (New York, 1964), p. 734. 
1900 , this signalled, to Mother Green, the beginning of a most noble, courageous, and far-sighted project "to prove to labor leader and capitalist alike that theirs was a community of interest". "She believes fully in the truth and justice of the Federation's oft-expressed sentiment that "the twin foes of industrial peace are the anti-union employers and the Socialists", and that the Federation's program, more or less equidistant from these short-sighted extremes, represented the equitable and progressive solution to industrial discord in early twentieth century America. From this perspective it is not surprising that Mother Green views the Federation's rabid anti-radicalism emerging during World War I as an aberration, an unexplained phenomenon that ushered in the NCF's rather rapid decline following the war.

Another significant point of view concerning the basic nature of the Federation is that which we might call the "Old Left" view, in many respects the opposite of the conservative Mother Green. From this perspective, the Federation is dominated by the classical open-shop capitalists who alternately cow and trick the labor leaders into serving the interests of aggressive capital. Characteristically, "old leftists" refer to "the anti-union, labor-baiting National Civic Federation"," the "chief purpose of which is to check every progressive tendency in trade unionism". 3 Philip Foner, by far the most prominent "old left" labor historian, takes a position very close to that assumed by Debs, Hillquit, and other Socialists during the days of the Federation. Foner's analysis is only slightly more sophisticated than the most dogmatic Marxists'; he admits that the business leaders were not consistently out to destroy the unions per se, but that they "sought to emasculate it, to ensnare the labor leaders into a conscious program of collaborating with the employers, robbing the workers of their vigor, militancy, and the spirit of their class". And as for the increasingly hysterical anti-radicalism which in time overtook the NCF, the "old leftists" explain it as simply the perennial stock-in-trade of

1 Marguerite Green, The National Civic Federation and the American Labor Movement 1900-1925 (Washington, D.C., 1956), p. ix.

2 Richard Bransten, Men Who Lead Labor (New York, 1937), p. 42.

3 Robert W. Dunn, The Americanization of Labor (New York, 1927), p. 72.

4 Philip S. Foner, The Policies and Practices of the AFL, 1900-1909 (New York, 1964), p. 61. Compare Foner's remarks with Morris Hillquit on the subject: "To the organized labor movement the policy of the Civic Federation is the most subtle and insidious poison. It robs it of its independence, virility and militant enthusiasm; it hypnotizes or corrupts its leaders, weakens its ranks, and demoralizes its fights." M. Hillquit to R. Easley, New York, June 16, 1911 (reprinted by Green, p. 166). 
the Federation capitalists, which was employed with abandon as the labor leaders became increasingly "emasculated".

The third rather clearly-defined outlook toward the NCF is provided by the historians of the "New Left", typified perhaps by Gabriel Kolko, whose The Triumph of Conservatism (1963) offered a significant fillip to and criticism of Marxist historiography on the period in question. The "new leftists" point out that only the smaller capitalists - of the National Association of Manufacturers, for example, which opposed the NCF - were open-shop or otherwise aggressively anti-union. In partial agreement with Green, then, and critical of the "old leftists", the newer Marxists view the businessmen of the NCF as being more aware of their long-range interests, and hence promoting industrial conciliation and social reform as a means of stopping the growth of Socialism, and engaging in the rationalizing and stabilizing of the political economy in partnership with the AFL and the government. A representative incident tending to support this analysis was the censure of D. M. Parry of the NAM by the Wall Street Journal on April 16, 1903, following Parry's initiation of an open shop campaign; the eminent Journal did not favor his attack on organized labor. According to the "new leftists", the NCF represented the major capitalists, who felt that working with the AFL in collective bargaining, and mediation and arbitration efforts, and toward progressive reform was in their best interests, not opposing such institutions and directions. ${ }^{1}$ Concerning the NCF's anti-radicalism, the "new" and the "old" Marxists both see capital's role as clearly the dominant one, with the emphasis on fighting radicals ascending as business overpowers labor in the Federation partnership.

Though I find the latter point of view the most sound single historical approach to the Federation, I feel it does not adequately deal with the role of the labor leaders of the NCF. It would seem that the record of the Federation discloses a great interest on the part of the AFL leadership in a consistent policy of anti-radicalism to insure their control over their rank and file and their own survival as the representatives of labor. They would therefore have provided as much impetus to the Federation as its business leaders and have found the fight against the radicals at least as important as the men of big business did. Viewed in this way, anti-radicalism was an ever-present motive to both sides and in its extreme form during and after the War, represented perhaps nothing so much as the fact that the heads of labor were forced to go to great lengths to suppress the threat they

1 James Weinstein, "Gompers and the New Liberalism, 1900-1909", in: Studies on the Left, Vol. V, No 4 (Fall 1965), reprinted by For A New America, ed. by James Weinstein and David W. Eakins (New York, 1970). 
felt from below. Being in many ways closer to it, the labor leaders could be said to always have felt the danger that labor militancy presented to them and their "mutually satisfactory contracts", in more acute form than the somewhat more secure men of capital. And it seems almost unnecessary to add that radicalism and labor militancy were virtually synonymous to the NCF figures.

Reed clarifies the basic labor relationships: "Gompers was more to the right than the Executive Council of the AFL and the AFL itself somewhat more to the right than the rank and file in the unions." 1 The labor contract (and with it, the closed shop) was tendered to capital, via the NCF, as the chief instrument of industrial peace and stability. Gompers pointed out to business that only through the union's labor discipline could a reliable work force exist:

"To every student, and particularly to those who are active in the labor movement, it is a fact beyond question and so easy of demonstration that I am astounded to find that it should escape the attention of the average man, and it is this: That there is no strike of workingmen so bitterly conducted, in which there is such hostility, in which there is so much lawlessness or violence as the strike of the non-union men, the strike of the unorganized men."2

He goes on to say that unions "prevent the emotional action of the men" and provide "restraint". We are getting at the substantive reasons why business and labor united to form the NCF, and uncovering the source of the NCF's anti-radicalism.

From this perspective, Harvey's brief introduction to the Federation, in contrast to Commons's quoted above, is superior:

"The National Civic Federation grew out of the Civic Federation of Chicago, a body which was active in that city at the time of the Pullman strike of 1894. Ralph Easley, who was then secretary of that organization, conceived of making it a national body with its chief interest centered in effecting conciliation in labor disputes. This he accomplished in time to avert the threatened strike in the anthracite coal fields in 1900 . A year later the same committee of the National Federation worked to settle the Albany street-car strike, the United States Steel Corporation strike, and the controversy between the National Metal Trades Association and the International Association of Machinists."3

1 Louis S. Reed, The Labor Philosophy of Samuel Gompers (New York, 1930), p. 117.

Samuel Gompers, Labor and the Employer (New York, 1920), p. 277.

3 Rowland Hill Harvey, Samuel Gompers: Champion of the Toiling Masses (Stanford, 1935), p. 145. 
Lorwin goes to the heart of the matter, highlighting the importance of the NCF to the labor leaders and implying a great deal about the Federation's anti-radicalism:

"Indeed, allowing for differences in composition, geographic distribution, and ideas, a certain similarity can be detected between the National Civic Federation and the anti-union employers' associations. Both were protests against militant unionism [...]. The Civic Federation proceeded with more sophisticated or enlightened methods; but it was bent on pulling the teeth of aggressive unionism. It had no tolerance for the sympathetic strike or for the strategic strike which ignored contracts."1

Gompers, Mitchell, et al. of the AFL joined the NCF for just such purposes as Lorwin cites. In fact this identity of interests leads him to note in the same paragraph that "the national employers' associations frequently assailed the National Civic Federation for allowing itself to be the cat's paw of organized labor." Harvey also observes the perspicacity of the non-union employers: "To the National Association of Manufacturers the organization [the NCF] was but an adjunct of the American Federation of Labor."2

Bransten speaks of the relationship between AFL leaders and the NCF in a statement to which both "old" and "new leftists" would subscribe:

"The AFL produced a good many leaders in the image of the oaken Gompers, obsequious before the great of the National Civic Federation and hard on the membership whom they ruled with an iron hand. Settlements over the heads of the membership were not uncommon, bribes to business agents by employers were not unusual."3

Although Bransten is, in the main, accurate here, his charging Gompers with being "obsequious" to the business interests of the $\mathrm{NCF}$ is somewhat misleading, for it downplays the positive needs which the NCF helped meet for the AFL leaders: namely, assistance in controlling a rank and file which wanted more than they did. This is not to say, of course, that business did not also have a great stake in the process, but this fact should not make us forget the important differences between labor leaders and union membership - and the importance

1 Lewis Lorwin, The American Federation of Labor (Washington, D.C., 1933), p. 84.

2 Harvey, op. cit., p. 141.

3 Richard O. Boyer and Herbert M. Morais, Labor's Untold Story (New York, 1955), p. 182. 
of this often very antagonistic relationship on the anti-radicalism of the NCF.

But if labor leaders were getting what they needed from the NCF, by ways of increased leverage on their members, it follows that the laboring man was not. "In spite of his [Gompers's] defense of the National Civic Federation's activities, labor lost confidence in its impartiality in industrial disputes." 1 This loss of confidence began setting in as early as 1903, due mainly to the growth of Socialism and the unwillingness of employers to grant concessions to favor the AFL labor leaders. The confluence of these two factors made it increasingly hard for the leaders to control the workers, perhaps especially after 1905 when the establishment of the Industrial Workers of the World raised the specter of militant industrial unionism in concrete form.

We are now in a position to understand the truth of two apparently contradictory statements: that the NCF was "the cat's paw of organized labor", 2 and that the NCF was "concerned with settling strikes - and often settlements it applauded were disastrous to unionism". ${ }^{3}$

A brief look at the NCF's activities in terms of three strikes in the first years of the century is revealing. In the unsuccessful strike of the Amalgamated Association of Iron, Steel and Tin Workers against U.S. Steel in 1901, the withholding of support by top AFL leaders - NCF members - was the decisive factor. Perlman and Taft speak of the negative influence of the NCF on the local union leadership and the excessive consideration by Gompers and Mitchell for their "trustworthiness" in the eyes of the NCF employers. These conservative labor historians assert that had the strikers had the cooperation and support of their AFL-NCF labor leaders, the strike would have probably been victorious. ${ }^{4}$ Ware goes a step further and considers the strike failure an example of how the AFL became virtually a "Morgan partner" via the NCF. In his view, such cooperation served to "cut the claws of aggressive labor leadership" and did much to encourage the development of the anti-radical policies of the AFL and NCF. ${ }^{5}$

In July, 1903, the Buffalo Union Furnace Company, owned by industrialist Mark Hanna, one of the NCF's most prominent founding members, was struck over an instance of anti-union discrimination.

1 Foster Rhea Dulles, Labor in America (New York, 1949), p. 194.

${ }^{2}$ Lorwin, op. cit., p. 84.

3 Ibid., p. 85.

4 Perlman and Taft, op. cit., pp. 101-106.

- Norman Ware, Labor in Modern Industrial Society (New York, 1935), pp. 321-323. 
The strike broke the contract negotiated only three weeks before, and prompted the company to communicate to Gompers an offer to allow the blast furnace workers to reorganize into a new union which would be recognized - if it were to be better "controlled" by the AFL. Under Gompers's direction this is exactly what was arranged, after the strike was permitted to die. ${ }^{1}$

In 1904, August Belmont replaced Hanna as chairman of the NCF's Industrial Department and was himself beset by an embarassing strike. The street-car employees of his Interborough Rapid Transit Company were threatening to strike, so he offered to resign his post (which automatically carried with it the title of President of the NCF) to save Gompers and his labor colleagues in the Federation discomfort. They not only refused to hear of Belmont's resignation but declared that they would forbid the strike. Alton B. Parker, who was later President of the NCF himself, describes the NCF labor leaders' tireless efforts for Mr Belmont and the cause of labor discipline:

"The whole Interborough System was tied up [...] Messrs. Gompers, Mitchell, Stone and Mahon, who were on the scene, immediately issued a public statement declaring that the strike was in direct violation of orders - aye, that there was no occasion for it. They ordered the men back to work, thus virtually breaking the strike and making good their promise to Mr. Belmont."2

Certainly the disaffection of labor toward the NCF was enhanced by such behavior of its labor members. Indeed, in the last two examples, the employers were both chairmen of the Industrial Department and Gompers et al. supported their positions against the union in each case.

This disaffection led the NCF to turn from its original emphasis on direct mediation and conciliation, ${ }^{3}$ to a strong interest in legislation to do the job for them. "From its attempts directly to avert strikes, the Federation in later years turned more and more to trying to have laws enacted providing for mediation and arbitration." As a measure of this shift in emphasis, there appear only two articles on NCF arbitration of strikes in the National Civic Federation Review between

1 Bernard Mandel, Samuel Gompers (Yellow Springs, Ohio, 1963), pp. 243-246.

2 Reprinted by Boyer and Morais, op. cit., p. 139.

3 Green, characteristically, has no explanation for this shift, owing to the fact that she everywhere devotes herself to defending the NCF's image. The best she attempts is to refer to unfavorable "economic conditions" obtaining after 1905, a highly dubitable comment. See pp. 69-70.

4 Clarence Bonnett, Employers' Associations in the United States (New York, 1922), p. 412. 
1907 and $1920 .^{1}$ Another part of this more indirect attempt to waylay industrial strife was the publicizing of employers' voluntary efforts to provide benefits, such as lunch rooms, for their employees, "From 1907 to 1914 [the NCF] had become interested in industrial welfare work." 2 As always, anti-radicalism can be seen as the motivating force. To quote Ralph Easley, NCF Secretary and main organizer: "there is perhaps no better antidote for radical attacks upon present institutions than intelligent, genuine and wisely directed welfare work."3

"It was Gompers who encouraged the Federation and Easley to begin and to continue the campaign against the radicals. [...] In the eyes of Gompers and the AFL hierarchy the great menace to organized labor in these years was radicalism." Although Green refers to the Red Scare period as "these years", her statement can be applied to really all the years of the Federation. Perhaps because she discounts the National Civic Federation Review as a source, ${ }^{5}$ more probably because of the attendant implications, she is unable to see that the fear of labor radicalism always inspired the NCF's tactics, not an abstract, noble statesmanship which somehow, inexplicably, "degenerated". Green does not notice very much anti-radicalism in the NCF before the War, and what she does notice she dismisses as merely "philosophical". In fact, she misses much; for example, all three of the issues of the National Civic Federation Review for 1909 are heavily weighted with strident diatribes against the radicals. ${ }^{6}$ And it was precisely baecuse the anti-radicalism was basic to the NCF's defense of organized labor that it was at no time merely "philosophical". The fact that explicit anti-radicalism began to appear with increasing prominence as the Federation's early period of mediatory work was clearly failing (by about 1908-1909) and as the Socialists and Wobblies were gaining strength, is certainly not accidental. Anti-radicalism was basic to the existence of the Federation and was always being expressed in one form or another.

As the Wobblies can be said to have represented in obvious form the menace of labor radicalism, with their stress on industrial action,

1 See Appendix. The articles appeared in the February, 1912 Review (Vol. III, No 11) and the June 15, 1919 Review (Vol. IV, No 15).

${ }^{2}$ Lorwin, op. cit., p. 113. See also Appendix for numerous examples in the issues of the Review.

${ }^{3}$ Quoted in Dunn, op. cit., pp. 204-205.

4 Green, op. cit., p. 469.

5 In that part of her bibliography called "An Essay on the Sources", she rather inexplicably says that the issues of the Review "yield little information to the historian of the Federation".

- See Appendix. 
Green's approach (and many others') to them is important. She mistakenly states that the IWW's "membership and influence declined considerably after 1913". ${ }^{1}$ Actually, their greatest upsurge in membership and influence took place 1916-1917. And so, having virtually ignored them before 1913, she does so completely after that date. I believe this is indicative of the attitude which tends to see radicalism, in the eyes of the Federation chiefs, as almost strictly political and limited to Socialist politicians, intellectuals, theorists, "pro-Germans", and pacifists. But because the NCF was in fact concerned all along with labor radicalism as a practical problem due to its direct bearing on industrial stability - the Wobblies received much more attention than is generally thought. ${ }^{2}$ With the coming of the War-time repression, this becomes easier to see. "Compared with the IWW, only a relatively small number of Socialists had been rounded up. It was the IWW that was under fire, and the Review bunch [International Socialist Review] had been spared because of the word 'Socialist' in the title."3 Gompers himself helps us keep in mind that labor unrest was what was understood as radicalism, not, for example, merely "philosophical" Socialism: "during war-time, the secretary of my local union, Morris Brown, and other cigar-makers - all Socialists - came to me to arrange a conference for them through the N.C.F. to adjust an industrial dispute. I enjoyed rendering the service." 4

The sedulous work of Easley in converting Gompers from his earlier pacifism $^{5}$ to support of American involvement was probably unnecessary. For one thing, the war provided the perfect time for an antiradical campaign. In fact, by 1915 , Gompers was publicly asserting "that strikes in the munitions plants and in the machinery trades had been instituted by German agents." 6 "At the annual meeting of the Civic Federation held in New York in January, 1916 [...] I [Gompers] made my first public preparedness speech."7 And with the war itself,

1 Green, op. cit., p. 180.

${ }^{2}$ Melvyn Dubofsky, We Shall Be All: A History of the IWW (Chicago, 1969). Shows the partnership between employers, AFL and government so often employed to meet the Wobblies' organizing efforts; see especially Chapters 15 and 16.

3. Ralph Chaplin, Wobbly (Chicago, 1948), p. 287. See also pp. 245, 301, 322, 331-332 re AFL hostility and cooperation with the government.

4 Samuel Gompers, Seventy Years of Life and Labor, II (New York, 1967), p. 116.

5 John Steuben, Labor in Wartime (New York, 1940), p. 19. Also, Lorwin, op. cit., pp. 138-139.

- Green, op. cit., p. 366.

7 Gompers, Seventy Years of Life and Labor, p. 332. 
labor's power grew enormously. The Committee on Labor, of the Council of National Defense, dealt with wages and hours, collective bargaining, and the health and welfare of the employees of the war industries. Gompers chaired that Committee, and received the government's recognition of the principle of unionization in return for a "no strike" pledge. In every government venture in war production, an area rather broadly defined, labor relations were handled by AFL men. The bargain by which unionization was recognized in return for "no strikes" was probably sufficient reason in itself for an anti-radical drive, and the war-time laws (e.g. the Espionage and Sedition Acts) certainly provided teeth for disciplining unruly labor elements. ${ }^{1}$

During the war the AFL's influence on the NCF was paramount, and Green correctly notes that "Easley's anti-radical campaign was waged for organized labor". On September 12, 1917, Easley created the League for National Unity, as a special branch of the NCF; the League's specialty was to brand any radical tendencies (very loosely defined) as German-inspired, if not German-financed. It worked in close cooperation with George Creel's Committee on Public Information, which was busily organizing propaganda for the government. ${ }^{2}$ The NCF extended every possible facility to Gompers in his capacity of labor administrator for the government, part of which consisted in undercover sleuthing for the government as well as tireless attacks, reprinted widely, against all radicals, and, increasingly, liberals, too. In a communication to Theodore Roosevelt, Elihue Root indicated the important industrial focus to this work: "The danger of Socialism and anarchy and the seriousness of strikes is just so much lessened by the earnestness"3 of Easley's League for National Unity.

Despite all this and so much more, Mother Green is yet able to write that, "unknowingly the leaders of the NCF had been caught up in the tides of prejudice and super-patriotism which had swept over the nation, destroying opportunity for independent action and the free play of opinion." A After documenting the very assiduous labors by which the NCF (and others, of course) created these forces, it is incredible that she can speak of the NCF leaders as "unknowingly" being swept up by them. Very similar, and equally faulty: "The failure of Easley and his co-workers only reflected America's failure

1 See Chaplin and Dubofsky cited above re the IWW, for example.

2 Critics of the NCF have made much of not only the excesses of both the League and the CPI, but of the alleged extra-constitutional methods involved in their joint efforts against individuals. Appropriately, Creel mentions not a word regarding Easley and the NCF in either his How We Advertised America (1920) or his autobiography Rebel at Large (1947).

${ }^{3}$ Green, op. cit., p. 391.

- Green, op. cit., p. 392. 
- the psychoneurosis of a people which had lost its moral stamina, which was spiritually ill-equipped to face the transition from war to peace." Empty phrases such as these serve only to mystify historical processes, not clarify them. Thus, mysteriously, "the American people" single out the Reds as the cause of all their woes and decide to have a Red Scare.

Among the many revealing Red Scare phenomena was the close, working alliance between Easley, Gompers, and Harding's FBI chief, Burns, the noted labor spy. Burns provides the key to the relationship:

"It is important at this time that the employers of the country uphold the hands of Samuel Gompers because the I.W.W. elements are fighting him at every turn; and, whatever our opposition to Mr. Gompers on certain questions may be, there is no comparison between present conditions and those which would obtain if the I.W.W. policies should win and the A.F.L. be destroyed."2

Easley went on to guide the NCF in strongly opposing the recognition of the USSR, attacking old age pensions as "socialistic", and hiring Archibald Stevenson, chief counsel to the New York state "Lusk Committee", and attacking the schools for their "radical" and "bolshevist" orientations. One of his most serious misadventures in the latter field was his espionage and intrigue work against the Interchurch report on the 1919 Steel strike, which included secret communications with top U.S. Steel executives. But it must not be concluded that even in Easley's most bizarre anti-radical moments he was not dedicated to serving the AFL by exposing its enemies. Note, for example, the fact that only weeks after Easley had been seen helping U.S. Steel by attacking the churchmen involved in the Interchurch investigation, he warned Gompers, in October, 1920, of an impending drive on the unions financed by U.S. Steel, Standard Oil, and Julius Rosenwald. ${ }^{3}$

The NCF declined mainly because it had accomplished its task. The forces of labor militancy were successfully suppressed, and the Federation's pioneering work in mediation and arbitration had been taken over by the Department of Labor and the various governmental arbitration boards. When industrial unionism did appear in the thirties, and the NCF had virtually disappeared from the scene, the institutions the NCF had firmly established - including that of collec-

1 Green, op. cit., pp. 392-393.

2 Quoted from Norman Hapgood, Professional Patriots (New York, 1928), p. 100. See also Sidney Howard, "Our Professional Patriots", in: New Republic, September 10, 1924. Howard describes Burns's files benefiting Gompers as “a convenient source of A.F. of L. propaganda against renegade unions".

3 Philip Taft, The AFL in the Time of Gompers (New York, 1957), pp. 230-231. 
tive bargaining itself - were at hand to wed the new industry-wide unions to a stabilized labor-management system.

The anti-radicalism of the Red Scare, then, had been with the National Civic Federation all the way along, in various forms and temperatures, as a function of its very existence.

\section{APPENDIX}

Notes on the National Civic Federation Review, September 1907 to November 1920 (Vols III-V)*

September, 1907 (Vol. III, No 1) Main emphasis of the issue is the voluntary effort of employers to improve the welfare of their employees, by voluntarily providing lunchrooms, exercise areas, etc. Also highlighted was an article by Samuel Gompers decrying child labor.

February, 1908 (Vol. III, No 2) Prominent articles discuss compulsory arbitration (collective bargaining and voluntary arbitration seen as preferable solution) and the issue of anti-trust regulation. Also featured are photographs of the eighth annual NCF dinner held December 16, 1907, in which Gompers, V. Everett Macy, members of the Harriman and Rockefeller families can be seen dining together.

May, 1908 (Vol. III, No 3) The establishment of the Woman's Committee is announced. Editor Easley contributes two articles praising Gompers ("that great statesman of labor"). Major article decries "Socialist Sunday Schools", in one of the Review's earlier pieces directly attacking the radicals.

September, 1908 (Vol. III, No 4) Front page announces "Trade Agreements to be Promoted" expressing the Federation's emphasis on contracts. Rest of issue is devoted to news on welfare work, the Woman's Committee, anti-trust discussion, and Gompers's upcoming trip to Europe.

March, 1909 (Vol. III, No 5) Report on 9th Annual Dinner, entitled "Benefits of Trade Agreements Undisputed". More news on welfare work plus several anti-radical articles: "Socialism's Menace to the Family" (in which Andrew Carnegie's latest book on the subject is touted), "Socialists Active in the American Educational Field", "Socialists Plan to Undermine American Army and Navy", and a smaller but interesting piece, "A Grotesque Travesty of Lincoln's Speeches: American Labor's Good Whole Cloth Cut Up and Made into Socialistic Patchwork".

July, 1909 (Vol. III, No 6) Uniform state legislation for regulation

* Materials made available by courtesy of the Stanford University Library. 
in a variety of areas is urged, advances in "welfare" benefits ceded workers by employers is discussed, and news of the Woman's Committee included. Prominent articles: "A Policy of Retrogression" (in which the National Association of Manufacturers' "eighteenth century stand toward organized labor" is castigated), "Insidious Methods of the Socialist Press Propaganda", "Gospel of Despair to Jewish Immigrants", and "Representative Labor Men Condemn Socialism".

November, 1909 (Vol. III, No 7) Workmen's Compensation legislation is urged and employers' welfare work in New York garment trades publicized. Rest of issue is devoted to: "The Two Irreconcilable Foes of the Civic Federation: Anti-Union Employers and Revolutionary Socialists Oppose Federation's Program for Industrial Peace", Socialism and American Labor Unions", "The Inconsistency of Christian Socialism", "No Violence in Socialist Program, Says W. D. Howells", and "A Socialist School in New York City". (Unless otherwise noted the articles were written by Ralph Easley or his assistant Ada C. Sweet in the great majority of cases.)

March, 1910 (Vol. III, No 8) Workmen's compensation for industrial accidents is held to be a priority for legislation and welfare work is featured, including this typical article, regarding the Metropolitan Life Insurance Company, "The Spirit of the Corporation Towards its Employees".

September, 1910 (Vol. III, No 9) Issue devoted to the promotion of uniform state regulatory laws in such fields as labor law (regulation of child labor, accident compensation), motor vehicles, dairy regulation, and many others.

July, 1911 (Vol. III, No 10) Front page declares "Workmen's Compensation the Keynote". Gompers provides an attack on the Socialists entitled, "Organized labor and the NCF". Employers' efforts for women employees (e.g. safety, lunch rooms) is covered under the "welfare" heading.

February, 1912 (Vol. III, No 11) Annual meeting, to be opened by President Taft, "To Promote Industrial Peace and Progress". Stationary firemen's president Healy contributes "Stinging Rebuke for Socialist Intriguers"; similar articles include, "Doctrine of Class Hatred Smitten Hard", "The Press Emphatically Endorses Labor's Rejection of Socialism", and "Socialism and the NCF". Easley provides a long defense of Gompers after the Los Angeles Times bombing by the McNamaras. Model workmen's compensation and pure food and drug bills are pushed, and Marcus Marks of the Federation is lauded for successfully arbitrating between the Danbury Hat Makers and the United Hatters. In addition to some welfare news, the amendment of the Sherman Act is called for, and it is suggested that public utilities 
be regulated somewhat "without interfering unduly with management". December, 1913 (Vol. III, No 12) Newlands Act "Becomes Law, Averts Railroad Strike". Other regulatory legislation requested again and efforts for "better relations" urged in "To Study Causes of Industrial Discord" article. "The Truth About Wages and Vice" appeared, a study of working conditions in New York department stores, criticized (outside the Federation) as a whitewash, conducted for the benefit of the stores - dues-paying members of the NCF. Also featured is "A Labor Men's Story of the Paterson Strike: Aftermath of the IWW Reign of Violence, Intimidation, and Graft".

March, 1914 (Vol. IV, No 1) Establishment of a Federal Trade Commission is urged, as well as "reasonable" trust regulation. "Cooperation" held to be the key to passage of pure food, workmen's compensation acts. Also, "Dr. Babson and his IWW Nightmare", and a smaller piece, "A Socialist Challenge Squarely Met".

May, 1914 (Vol. IV, No 2) In addition to the familiar topics of welfare work, the Woman's Department, and workmen's compensation, rural problems and prison reform are considered in this issue.

(Between May, 1914 and December 5, 1918, the Review was not published. Its resumption brought a greater frequency of publication, but the issues appeared with the same irregularity as before. Inasmuch as the Review resumed with Vol. IV, No 7, it must be assumed that the four and a half years' discontinuance represent the missing issues, Vol. IV, Nos 3-6.)

December 5, 1918 (Vol. IV, No 7) The cover story, "Samuel Gompers' Great Message", by Chester M. Wright, is subtitled "Efforts of Disloyalists, Fight Against Anarchy Must Continue", and begins: "Samuel Gompers returned from his remarkable tour of Europe bringing warning of these things: Bolshevism, Pacificism, Pro-Germanism, and Socialism. And for the most part he wraps all of these things up in one package and puts a composite lable on the mess." The other significant articles are "War Activities of the NCF", the first installment of T. Everett Harre's series "Shadow Huns and Others" (attacking The Nation, New Republic, etc.), "Red Labor Speaks", "Leaders in the Fight Against the Enemy Within", "The British Labor Party's Program" (attacked as "scheme for Revolutionary Socialism"), and "The Forces of Disorder".

December 20, 1918 (Vol. IV, No 8) On its front page, the issue of "Industrial Reconstruction" is introduced, and the "Works of the National War Labor Board" extolled. The remainder is almost exclusively given over to anti-radicalism: "Shadow Huns and Others" (II), "Bolshevik 'Industrial Government", "Nursing the Viper", "Closer Unity of Labor and Capital", "Bolshevism in Action", "Danger- 
ous Church 'Entertainment"', and "The Class War Propaganda". January 10, 1919 (Vol. IV, No 9) The question of the League of Nations is discussed in rather negative fashion under the title, "Can All Wars Be prevented?: Shall We Abrogate the Constitution? Foreign Nations Would Decide American Questions". In addition to some attention to the Woman's Committee, the other prominent articles are: "Bolshevism Convicted Out of Its Own Mouth", "Shadow Huns and Others" (III), and "Bolshevik 'Industrial Government"" (II). January 25, 1919 (Vol. IV, No 10) This issue is devoted largely to issues of foreign policy - The League, Poland, Czechoslovakia, and post-war reconstruction - plus Harre's "Shadow Huns and Others" (IV), devoted to the fight against "parlor Bolsheviks".

March 25, 1919 (Vol. IV, No 11) "Europe's War Labor Experience" is discussed, and "Harvester Industrial Council Plan" reports favorably on what seems to be very close to a company union plan for International Harvester Co. The remainder is almost all Red Scare material: "Radicals Mislead Churches About Labor" (subtitled, "Social Reconstruction Programs Put Forth by Catholics and Protestants Alike, Based on Views of Near-Bolsheviki, not on Ideas of Organized Labor"), Harre's provides a slight variation in his series, to keep abreast of the times, "Shadow Bolsheviki and Others", "America No Place for Bolshevism", and a racist (as well as anti-radical) article prompted by the Union League, "New York State Probe of Bolshevism Asked". April 10, 1919 (Vol. IV, No 12) In addition to slight attention to welfare activities - plant heating and ventilation explored and "Industrial Training a Way UP" - this issue is almost all anti-radicalism. "'Who's Who' in the 'New School"', "Smoking Out Hun Propaganda Nests", "Secret Hyphenated Propaganda", "Sapping the Foundations of Society", "The Red Glow of Bolshevism", "British Capital and Labor Unite: Opposed to Radical, Revolutionary Changes in Industry", and "The New Tragedy of the War: Bolshevik Class War Threatens to Invade Other Nations and Menaces Security of World".

April 25, 1919 (Vol. IV, No 13) "American Labor Mission Returns" sees ex-President Taft welcome Gompers from Europe and hail collective bargaining as "industrial democracy". Other major articles: "Sapping the foundations of Society" (II), "Menace of Recognizing the Russian Soviets" (echoing a Union League report), and "W. J. Ghent Makes Critical Analysis of "the Nation"”.

May 15, 1919 (Vol. IV, No 14) Main articles: "Labor and the Golden Rule", "Is America Worth Savings?”, “'Intellectuals' Invading Labor Field", "Compulsory Health Legislation Opposed by Labor", "Matthew Woll on the 'One-Big-Union' Idea" (AFL "does not countenance strikes of any kind which do not first meet with the approval of the 
international unions"; AFL opposed to industrial unionism), "Poisoning the Fonts of Learning", "Efforts to Revive German Music: Insidious Propaganda Under Guise of Art Resumed", "An American View of the Industrial Unrest", "Bolshevism in the U.S.", and "The Failure of Public Ownership".

June 15, 1919 (Vol. IV, No 15) Features Harre's "Out of Their Own Mouths", "Suppressed Facts About Bolshevism", "Bolshevik Bolsterings", "Pacifists Again Abet The Huns", "Railroad Brotherhoods an Object Lesson in Labor Progress: Organization Opposed to Radical Movements That Bring Misery and Ruin", "Recognize the Omsk Government", and, for only the second time in the whole of Vols III, IV and V of the Review, an article on arbitration, "Frank Morrison's Award in the Printing Case" (between Typographers' Union, Local 6 and the Publishers' Association of New York).

June 30,1919 (Vol. IV, No 16) The Review discusses the consumer and industrial reconstruction in England and France, and "Timely Points in Pope Leo XIII's Labor Letter" (of 1891), turning, as usual to antiradicalism: "Undermining the foundations of National Morale" ("propaganda in school text books" to be probed), "Labor Voices its Patriotism", and "Freedom of Teaching in the School" (which should not extend to radicals).

July 30, 1919 (Vol. IV, No 17) Front page features "Plot to Overthrow Government", which seconds the findings of the New York Lust Committee. Similarly: "Spargo's Camouflaged Socialist Propaganda", "'Minority Opinion' - or Sedition?", "British Official Reports Indict Bolsheviki", and "Bolshevik Buncombe Regarding Germany's Defeat". Also in the issue are minor articles on welfare work, work hours, and uniform milk standards.

August 30, 1919 (Vol. IV, No 18) Consideration is given to the plight of the farmers, plus a look at European Labor. Also, "Andrew Carnegie - the Friend of Labor" and "Great Leaders of the Union Labor Movement" (I). Of prominence in the anti-red vein are: "If Bolshevism came to America" and "I'd Fight for America,' says Stokes to Sinclair". George Creel is among the contributors to this issue.

September 30, 1919 (Vol. IV, No 19) A rather sober attitude marks this issue, characterized by "Our Paramount Problems" (to solve "Social and Industrial Unrest"), "The President's Industrial Conference", and "Square Deal Through Amicable Arbitration". Significant also is "Socialism or Social Reform in the Church - Which?" plus articles on the post-war European scene and "Great Leaders of the Union Labor Movement" (II).

January 1, 1920 (Vol. V, No 1) Biggest story is "Inviolability of Contracts" on the front page. Articles on industrial training to in- 
crease production, and on the Federation's opposition to compulsory health insurance also appear, but less prominently than "My Days Under the Bolshevik Reign of Terror", "Russia As Seen By ExMilitary Attache", "The Peace Covenant Labor Code: Menace to AFL Principles [...] International Socialism?" and "Socialism or Social Reform in the Church - Which?" (II).

May 10, 1920 ( Vol. V, No 2) Featured is "The Big Four Win Victory: Hold $90 \%$ of Membership of Railroad Brotherhoods Against Outlaw Movement Aiming to Destroy Organization and Promote 'One-BigUnionism"" (celebrating victory of union "discipline" over wildcat strikers). Following some discussion of industrial training and the state of the public schools, are four consecutive major anti-radical articles: "Democracy in Industry", "Socialism Unmasked", "What is Socialism", and "Bolsheviks Officially Admit Economic Failure". July 10, 1920 (Vol. V, No 3) Main topic, discussed in very general terms, "Is the Labor Problem Unsolvable?" occupies prime position. Great amount of explicit anti-radicalism throughout rest of issue: "Socialism Unmasked" (II), "Department on Study of Revolutionary Movements Established", "Plan to Create National Service Commissions: To Promote Defensive and Constructive Loyalty", "Need for Legislation Against Disloyalty" (quoting the federation's co-worker, special counsel to the Lusk Committee, Archibald Stevenson), "A Challenge to the Protestant Episcopal Church", "Revolution in U.S. Preached by Methodist Clergy", "Questions for Every Good American", "Pro-Bolshevik Propaganda by American Correspondents".

September 25, 1920 ( $\mathrm{Vol}$. V, No 4) Aside from consideration of some elements of the problems of agriculture the issue is given over to the fight against radicalism: "The Answer-Root of Revolutionary Radicalism", "Catholic 'Social Reconstruction Program' Analyzed", "Socialism Unmasked" (III), "Notable Books Make Timely Expose of Socialism", and "The Mountain Labored And -" (attacking the liberals of The Nation, New Republic, The Survey, etc.).

November 25, 1920 (Vol. V, No 5) The Review's last issue continues the pattern of predominant anti-radicalism with "Letters to Signers of Declaration Against Recognition of Soviet Russia", "Exposes W. Z. Foster's Charges", "Present Status of Socialist Party" "Socialism Unmasked" (IV), "Railroad Brotherhoods Condemn Illegal Strikes", "American Labor Breaks with International Federation: Repudiates Revolutionary Program", and "Catholic 'Social Reconstruction Policy' Analyzed". 